\title{
Figure of Speech in Novel of Mice and Men and Seek The Translation Quality from Two Different Gender Translator Version: What is the Influenced Factor?
}

\author{
Lailatun Najakh \\ Sebelas Maret University, Indonesia \\ e-mail: lailatunnajakh93@student.uns.ac.id \\ M.R.Nababan \\ Sebelas Maret University, Indonesia \\ e-mail: amantaradja@yahoo.com \\ Djatmika \\ Sebelas Maret University, Indonesia \\ e-mail:djatmika@uns.ac.id
}

\begin{abstract}
The analysis of novel cannot be drawn away from its figures of speech. Figures of speech every author is different and that beauty of writing attracts reader's interest. The following issue is about how this literary work can arrive closely to its original version when it is translated by two different gender of translator. Besides, translator may bring their own ideological gender background. Regarding to this issue, obviously, the quality of target text version is in a huge questioning. Further, this research used novel Of Mice and Men by John Steinbeck and pays attention to find out figure of speech found in novel Of Mice and Men, the translation techniques choose in that novel, and the impact of translation techniques to translation quality from two different gender translators. The research method of this research was descriptive qualitative with collecting data, validating data, and analyzing data in order to get result. The source of data were novel Of Mice and Men (Tikus dan Manusia) translated by Pramoedya Ananta Toer and Ariyantri E. Tarman. Data collection was using purposive sampling. This result showed that there were eight figures of speech found in novel Of Mice and Men. In terms of their translation techniques, the most applied techniques by female translators were established
\end{abstract}


equivalent and male translators were also established equivalent followed by creative discursive. In addition, the chosen techniques by female translator gave higher accuracy than male translator. Meanwhile the acceptability and readability were high from both translators. However, the result didn't find any correlation between gender ideology and the chosen techniques. The chosen techniques were more likely influenced by the translator job background. The background of male translator as the famous novelist gave his strong ideology also transferred to his work as translator. Meanwhile, the female translator worked faithfully to source text.

Keywords: Figures of Speech, Translation Techniques, Translation Quality, Gender

\section{INTRODUCTION}

Translation is an activity that becomes a bridge in the process of transfer information between source language (SL) and target language (TL). Meaning and translation has a very close relationship. Relate to this, translator's competence become the point to make translated work as natural as possible. Translator competence covers the knowledge, abilities, skills, and attitudes (Hurtado Albir \& Taylor, 2015). The competence of translator will determine the process and the product. The product of translator which becomes an urge to be discussed here is related to literary work. Later, we realize that novel becomes the most translated work. Based on the number of work, it drives translator with problems. In line with this issue, the notion of Fernández Guerra (2012) stated that translating literary work had too many problems. In translating the novel, the translator will find a variety of different language style form one novel to another. It happens because the style of each author's is different. The differences can be caused by the different background of authors. Therefore, novel has an artistic totality where many linguistics elements are on it. The uniqueness of figure of speech in novel is a challenge for translator to work carefully with the text being translated.

Furthermore, figures of speech in novel becomes an interesting thing to be studied considering readers can be attracted to certain novel because of its. The figures of speech as part of the diction is related to individual or characteristics expression or has high artistic value (Keraff, 2010). Keraff has classified the figures of speech into, (a) comparative figure of speech include personification, metaphor, hyperbole, and parable, (b) satire figure of speech include irony, cynicism and sarcasm, (c) Contradiction figure of speech include litotes and antithesis, (d) affirmation figure of speech includes repetition and ellipsis. Then, figure of speech has a gender relationship that is the female and male figures of speech. Women and men are different in verbal and nonverbal communication (Mahmud, 2010).

Some researchers already work on figure of speech with varied objects. Hendrastuti, Nababan, \& Wiratno (2013) used book called The Secret motivation to review the translation of metaphor which show an attitude Furthermore, Nila (2013) 
and Lilasari (2012) used novel as the object of research. However, Nila' research (2013) was limited to several types of figures of speech. They are metaphor, simile, and personification while Lilasari (2012) only examined live metaphor in his research. Further, Suprajaheni (2011) and Widiyantari (2012) did not examine the quality of translations product.

Furthermore, Ekawati, Sumarwati, (2012) who saw the figures of speech in the translation novel called The Kite Runner. But this research was limited to the figurative language and sees the benefits of using the language style. Then research on quality of translation and figure of speech has been done by Murtafi, Nababan, \& Djatmika (2017) who analyzed the repetition of figure of speech entitled A Thousand Splendid Suns, technique and quality using stylistics approach.

Related to female language features, Wahyuni (2015) in his thesis analyzed the features of the speech used by Margaret Thatcher in a TV interview by looking at the linguistic features used while Rahayu (2008) analyzed the variety of male and female languages with a pragmatic approach through conversational implicatures. Thus, this research not lies on the different gender from the author but focused on different gender of translator.

Based on above review, the researcher still found the gap in which this study focuses on all figures of speech in novel Of Mice and Men. Besides, this research not only sees the figures of speech on one translated version but it analyzed two translation version from translator with different gender.

Therefore, in this study the researchers analyzed the translation of the female translator's style of translation and the male translator by looking at the technique and quality of the translation (accuracy, acceptability, readability). The first translator by Pramoedya Ananta Toer (male translator) had been reprinted until 2005 by publisher Lentera Dipantara while the female translator, the researcher took the translation version from Ariyantri E. Tarman (female translator) published in 2017 by PT. Gramedia.

Furthermore, the translation techniques chosen by the translator will deploy the quality of the translation product. Molina \& Hurtado Albir (2002), provide eighteen translation techniques. Some of those are established equivalence, creation discursive, modulation, amplification and literal translation. For example:

ST: Evening of a hot day started the little wind to moving among the leaves.

TT: (Ariyantri)

"Malam yang gerah mendorong angin menyelinap di antara dedaunan.

(Pramoedya)

"Senja menutup siang yang terik membangunkan angin desir yang mengalunalun daun-daunan"

Source: (Steinbeck, 1965)

From the above, Ariyantri used established equivalent meanwhile Pramoedya applied creative discursive. Ariyantri's translation version was closely arrived to the source text meanwhile Pramoedya was far different from the source text.

Thus, translation is assessed by translation quality instrument proposed by Nababan (2012), it has three aspects, namely: accuracy, acceptability, and 
readability. Further, this research focussed to find out the kind of figure of speech in novel Of Mice and Men, the translation techniques used by two translators and the impact of translation techniques towards the translation quality.

\section{LITERATURE REVIEW}

\subsection{Translation}

Meaning and translation has tight relationship. According to Newmark in Suyawinata (2003) translating means transferring unit of linguistic aspect from one language into another language. Meanwhile, Nida \& Taber (1982) define translation as transferring meaning from source text into target text. In other word, transferring is not only dealing to the text but also the meaning from source text into target text. In line with the above definitions, (Newmark, 1988) stated that translation is rendering the meaning of a text into another language in the way that the author intended the text.

In short, translation is a process transferring source text into target text by focusing both in form and meaning.

\subsection{Translation Techniques}

This research refers to translation techniques proposed by (Molina \& Hurtado Albir (2002) in which they make clear distinction between techniques and procedures. Technique refers to translation product besides strategy refers to process.

According to Molina \& Hurtado Albir (2002), translation techniques have five characteristics, as follows:

a. Translation technique affects translation result

b. Techniques are classified by comparing source text and target text

c. Translation techniques affects in micro unit (word-phrase-clause-sentenceparagraph)

d. Be discursive and contextual depending on the social/cultural context

e. Translation techniques are functional, can influence as addition or reduction depend on its context.

In this research, researcher uses translation techniques proposed by Molina \& Hurtado Albir (2002). The researcher chooses this technique because those techniques are easy to classify each data.

There are 18 translation techniques classified by Molina \& Hurtado Albir, (2002) namely: adaptation, amplification, borrowing, calque, compensation, description, discursive creation, established equivalent, generalization, linguistics compression, literal translation, modulation, particularization, reduction, substitution, transposition, and variation.

\subsection{Translation Quality Assessment}

Translation quality is important to be assessed with two important reasons. First, to create dialectic relationship between theory and practice. Second, the importance of criteria and standard to assess the competence of the translator, 
Machali (2000:143). Furthermore, the reference of translation quality assessment is the translation product rather than the process of translation. The assessment refers to three main things: (1) determination of message transfer, (2) provision of message disclosure in target language, (3) the nature of target language, (Nababan, 2003:86). Based on three main this above, the quality of translation is assessed by accuracy, acceptability, and readability.

The assessment refers to the usage of words, phrases, clauses or sentences in the target language rules. An accurate translation product takes 3, less accuracy 2, and not accuracy 1 , an acceptable translation product takes 3 , less acceptable 2 , not acceptable 1 . Meanwhile, for readability, high readability takes 3, middle takes 3 and low readability takes 1 .

\subsection{Figure of Speech}

Simile. The word simile comes Latin. Based on Keraff (2010:138), is a explicit comparison. In other words, simile is an explicit comparison indicated by the use of conjunctions like, as, than, or as resemble. Simile and metaphor have the same definition that both compare the two things we deliberately consider the same. Both the difference is indicated by the use of conjunctions as, than or resemble. While, metaphors do not use conjunctions in comparing them.

Metaphor. Metaphor is a kind of analogy that compares two things directly without using conjunctions to compare them. Metaphor is a kind of comparative style of language is shortest, solid, neatly arranged (Tarigan, 2013).

Personification. Personification is a kind of figurative style of speech that depicts inanimate objects or lifeless thins as if it has human nature. The point in personification is tangible as though it were a human being, both in the actions feelings, and other human actions. In short, personification is a figurative language which sconsidered as human life (Suryasa, 2016).

Irony. Irony is a reference that wants to say something with a different meaning or purpose from what is contained in the sequence of words (Keraff, 2010). There are three ways that can be done to produce the language if irony which is stated the meaning contrary to the intention of mockery (Tarigan, 2009), namely:

a. The meaning contrary to the true meaning

b. Not based on the underlying reality

c. Inconsistency between hope and reality

Sarcasm. Sarcasm is a more rough reference of irony and cynicism. Sarcasm can be ironic, this style will always be hurtful and unpleasant to hear. Later on, sarcasm is a figure of speech which can led to threat and sarcasm does not need to be conveyed in implicature (Taylor, 2017).

Satire. Satire is a phrase that rejects or laughs at something. The difference in this form of majesty should not be ironic and usually criticize the human condition or weakness in order for change (Keraff, 2010). Furthermore, satire is a figure of speech that attacks humanity and society.

Hyperbole. This figure of speech that contains an exaggerated statement, by exaggerating something (Keraff:2010). 


\section{RESEARCH METHODS}

This study used descriptive qualitative design by describing the technique and the impact on translation quality from source text into target text occurred in Novel entitled Of Mice and Men. The data were all figures of speech found in that novel. Moelong (2005) states that qualitative research is a research type which does not include numbers and calculations. Lincoln and Cuba in Santosa (2017:49) explain that that the location of study as "focus determined boundary", which literally means a limit determined by the focus or subject or research so that the location of this study is not necessary geographic or demographic but may also media.

Media used in this study was novel Of Mice and Men and two translation versions. Participants in this study were all characters in novel Of Mice and Men. Then, the event was all sentences contain figures of speech.

Thus, data sources consisted of documents and informants. The documents include novel and its two translation version and informants were ratters to assess the translation quality. Sampling used purposive sampling because data were taken purposively to achieve research purpose. Collecting data were done by document analysis and FGD (Focus Group Discussion). In FGD, the instruments were used translation quality assessment by Nababan (2012) The translation was assessed in three aspects, accuracy, acceptability, and readability.

\section{FINDINGS}

In this research, the researcher found 8 kinds figure of speech. There were metaphor, simile, satire, personification, sarcasm, irony, hyperbole, and repetition.

\subsection{Figure of Speech Found in Novel Of Mice and Men}

Table 1 Kind of Figures of Speech

\begin{tabular}{llll}
\hline No & Kinds of Figure of Speech & Total & $\begin{array}{c}\text { Percentage } \\
(\%)\end{array}$ \\
\hline $\mathbf{1}$ & Metaphora & 48 & 39.7 \\
$\mathbf{2}$ & Simile & 18 & 14.9 \\
$\mathbf{3}$ & Satire & 13 & 10.8 \\
$\mathbf{4}$ & Personification & 13 & 10.8 \\
$\mathbf{5}$ & Sarcasm & 11 & 9.09 \\
$\mathbf{6}$ & Irony & 10 & 8.3 \\
$\mathbf{7}$ & Hyperbola & 6 & 5 \\
$\mathbf{8}$ & Repetition & 2 & 1.7 \\
\multicolumn{2}{c}{ Total } & $\mathbf{1 2 1}$ & $\mathbf{1 0 0 \%}$ \\
\hline
\end{tabular}

\subsubsection{Metaphor}

The example of metaphor data found in novel Of Mice and Men, as follows: ST/C1/P1: The water is warm too, for it has slipped twinkling over the yellow sands in the sunlight before reaching the narrow pool.

\section{(Ariyantri)}

TT001/C1/P7: Airnya hangat, mendesir di pasir kuning di bawah sinar matahari sebelum sampai ke penggalan sungai yang dangkal. 


\section{(Pramoedya)}

TT001/C1/P7: Airnya hangat karena sebelum mencapai kadungnya yang sempit, ia bermain-main dulu, beriak berkilau-kilauan melintasi pasir kuning dalam cahaya matahari.

In the example above, data belong to metaphor since it described the thing not in an actual behaviour. The water wa impossible twinkiling over, but this figurative language gave a beauty description to make reader understand and aware the condition of water flowing in that story so the reader felt like comes into the setting of place of that story.

\subsubsection{Simile}

ST015/C1/P8: A water snake slipped along on the pool, it's head held up like a little periscope.

\section{(Ariyantri)}

TT015/C1/P15: Ular air menyelinap masuk ke telaga, kepalanya terangkat naik seperti periskop mungil

(Pramoedya)

TT015/C1/P13: Seekor ular air meluncur di kedung menyebrang, dengan kepala tersembul, di atas permukaan seperti periskop kecil.

In the example above, the data put in simile because it compared two things with conjunction "like". It's held up like a little periscope was translated into simile also in target text.

\subsubsection{Satire}

ST034/C1/P13: "Yeah? How'd you eat. You ain't got sense enough to find nothing to eat."

\section{(Ariyantri)}

TT034/C1/P22: "Oh, ya? Lalu bagaimana kau akan makan? Kau tidak cukup cerdas untuk cari makanan."

(Pramoedya)

TT034/C1/P18: "Ha? Bagaimana makanmu? Akalmu tak sampai buat mencari makan."

The data above belongs to satire since it criticized the lack of Lennie as mental retarded person. Further, the speaker was George who felt desperate about his bestfriend called Lennie who rely on him in everything due to his lack. Satire is figure of speech which in the form of indirect attack towards the weakness of human, behaviours to create laughs (Tarigan, 2013:70).

\subsubsection{Personification}

ST003/C1/P1 : On the sandy bank under the trees the leaves lie deep and so crisp that a lizard makes a great skittering if he runs among them.

\section{(Ariyantri)}

TT003/C1/P78 : Di tepi sungai berpasir di bawah pohon, dedaunan terbaring kaku dan begitu kering sehingga seekor kadal membuat bunyi kerisik lantang ketika berlari melintas. 


\section{(Pramoedya)}

TT003/C1/P7 : Di tepi yang berpasir, di bawah pohon-pohon, daun-daunan tergantung gemulai ke bawah dan jadi gemerisik bila ada kadal-kadal berlarilarian diantaranya.

In the above example, the data was included to personification because it was comparison between leaves which was like a human who can lie, The source text was in personification and two translators still arrive at the same meaning and kind of figure of speech.

\subsubsection{Sarcasm}

ST047/C2/P25 : "Be a damn good thing if you was," George said viciously. "Save ever'body a hell of a lot of trouble."

\section{(Ariyantri)}

TT047/C2/P36 : "Bagus kalau itu terjadi,"kata George pedas."Jadi berkurang masalah buat semua orang."

\section{(Pramoedya)}

TT047/C2/P28 : “Jahannam, baiknya kalau memang begitu,"bentak George marah. "Kalau tidak, aduhai, orang akan lepas dari kesialanmu.'

The data above was an example of sarcasm, it was more than irony and always hurtful. Sarcasm in source text was also translated into sarcasm in target text. It was sarcasm which can led to threat and sarcasm does not need to be conveyed in implicature (Taylor, 2017:2)

\subsubsection{Irony}

ST035/C1/P14: George said,"I want you to stay with me,Lennie. Jesus Christ, somebody'd shoot you for a coyote if you was by yourself. .No, you stay with me. Your Aunt Clara wouldn't like you running off by yourself, even if she is dead."

\section{(Ariyantri)}

TT035/C1/P23: George berkata, "Aku ingin kau tinggal denganku, Lennie. Ya Tuhan, seseorang akan menembakmu, menyangka kau anjing liar kalau kau sendirian. Tidak, kau tetap tinggal denganku. Bibimu Clara tidak mau kau pergi sendirian, sekalipun dia sudah mati."

\section{(Pramoedya)}

TT035/C1/P18: George berkata," Aku minta engkau selalu dengan aku, Lennie. Ya Rasul, kalau engkau sendirian saja, engkau mesti ditembak orang seperti serigala. Jangan, engkau mesti tinggal dengan aku. Bibi Clara mu tak suka engkau bergelandangan sendirian, sekalipun dia sudah mati."

The above example was data of irony, this figure of speech was a reference to tell something oppositely with the fact. George told Lennie that somebody'd shoot you for a coyote because George felt that Lennie would be in trouble if he stayed alone but he did not really meant it. 


\subsubsection{Hyperbola}

ST061/C2/P35: There was a gravity in his manner and a quiet so profound that all talk stopped when he spoke.

\section{(Ariyantri)}

TT061/C2/P49: Ada daya tarik dalam gerak geriknya dan sikap tenang yang

begitu dalam, sehingga semua pembicaraan terhenti ketika ia bicara.

(Pramoedya)

TT061/C2/P38: adalah suatu gaya dalam langkah lakunya dan dalam

kelembutan suaranya hingga semua percakapan terhenti bila ia membuka mulut.

In the example above, the data was hyperbole in which that sentence was an over description about the charismatic skinner character namely Slim. The data was translated in hyperbole also in both version of target text.

\subsubsection{Repetition}

ST099/C4/P84 : Candy's face had grown redder and redder, but before she was done speaking, he had control of himself.

\section{(Ariyantri)}

TT099/C4/P10 : Wajah Candy semakin memerah, tapi sebelum perempuan itu selesai bicara, lelaki tua itu berhasil mengendalikan diri.

(Pramoedya)

TT099/C4/P79 : Muka Candy kian lama kian merah, tapi sebelum perempuan itu habis berbicara ia telah dapat membesarkan perasaanya

The example above was the example of repetition because the repetition of word redder and redder.

\subsection{Translation Technique Used By Two Translators}

The following chart was translation techniques applied by male translator named Pramoedya Ananta Toer,

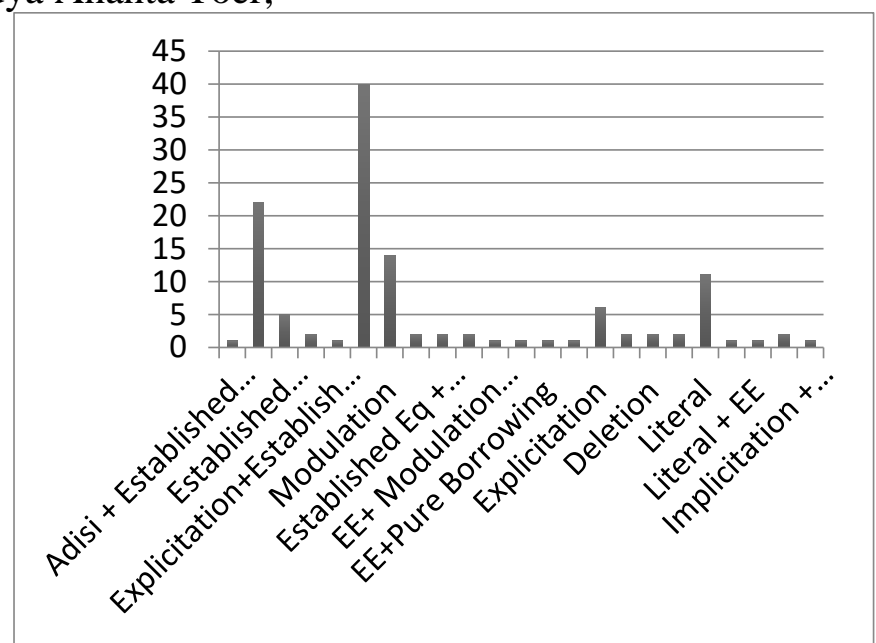

Figure 1. Translation Techniques Applied by Male Translator (Pramoedya A. Toer) 
Then, the below chart shown the translation techniques applied by female translators named Ariyantri E. Tarman as follows:

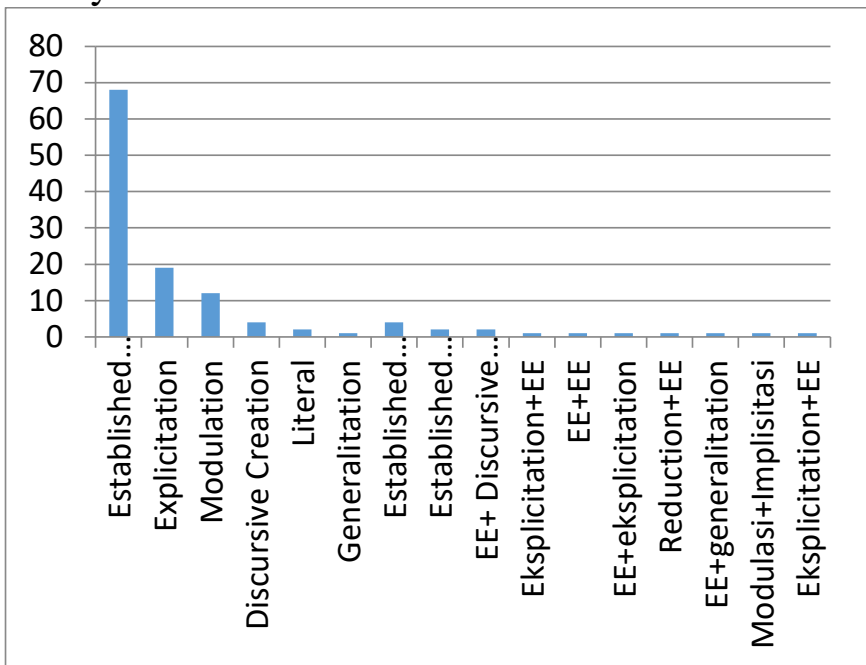

Figure 2. Translation Techniques Applied by Female Translator (Ariyantri E. Tarman)

From the data above, the chosen technique by male translator beside established equivalent was discursive creation and it was followed by other combination techniques. Then, female translators mostly applied established equivalent in which it influenced the translation quality which would be assessed in terms of accuracy, acceptability, and readability.

\subsection{The Impact of Translation Techniques toward Translation Quality}

The above chosen techniques gave impact to the translation quality in which the researcher referred to the score range as follows;

Table II. Category of Translation Quality

\begin{tabular}{llll}
\hline No & Category & Range of Score \\
\hline $\mathbf{1}$ & $\begin{array}{l}\text { Accurate, acceptable, high } \\
\text { readability }\end{array}$ & $2.6-3.0$ \\
$\mathbf{2}$ & $\begin{array}{l}\text { Less accurate, less acceptable, } \\
\text { medium readability }\end{array}$ & $2.0-2.5$ \\
$\mathbf{3}$ & $\begin{array}{l}\text { Not accurate, not acceptable, } \\
\text { low readability }\end{array}$ & $0.0-1.9$ \\
\hline
\end{tabular}

The above range would be a reference to draw the translation quality from male and female translator. Following its translation techniques, the average score from two translators were as follows; 
Table 3. Average Score of Ariyantri E. Tarman (Female Translator)

\begin{tabular}{|l|l|l|l|l|}
\hline \multicolumn{3}{|c|}{ Average Score } & \multirow{2}{*}{ Total } & \multirow{2}{*}{ Average } \\
\hline Accuracy & Acceptability & Readability & & \\
\hline 8.4 & 5.96 & 2.98 & 17.54 & $17.54: 6$ \\
& & & & $\mathbf{2 . 9 2}$ \\
\hline
\end{tabular}

Table IV. Average Score of Ariyantri E. Tarman (Female Translator)

\begin{tabular}{|l|l|l|l|l|}
\hline \multicolumn{3}{|c|}{ Average Score } & \multirow{2}{*}{ Total } & \multirow{2}{*}{ Average } \\
\hline Accuracy & Acceptability & Readability & & \\
\hline 6.9 & 5.5 & 2.77 & 15.1 & $15.1: 6$ \\
& & & & $\mathbf{2 . 5 1}$ \\
\hline
\end{tabular}

From the table above, it could be concluded that the translation quality Of Mice and Men which was translated by Ariyantri E. Tarman was 2.92. It meant that the translation quality was high. Meanwhile, the translation quality of Mice and Men which was translated by Pramoedya A. Toer was 2.51. It meant that the translation quality was medium. From the calculation above it was found that translation quality from female translator was better than male translator. Later, in discussion it will discuss more the differences and the factor contribute it.

\section{DISCUSSION}

\subsection{Metaphor}

ST002/C1/P1 : On one side of the river the golden foothill slopes curve up to the strong and rocky Gabilan mountains,

TT002/C1/P7: Di satu sisi sungai, lereng kaki bukit yang keemasan melekuk menuju Pegunungan Gabilan (Ariyantri)

TT002/C1/P7: mengarang sebuah anak bukit keemasan melengkung ke atas, menggabungkan diri dengan pegunungan cadas Gabilan. (Pramoedya)

The data above was the example of metaphor. It was translated into lereng kaki bukit yang keemasan by Ariyantri meanwhile Pramoedya was translated into sebuah anak bukit keemasan. Ariyantri deployed established equivalent and the translation quality is high in terms of accuracy, acceptability, and readability. In addition, Pramoedya deployed discusrive creation and lower the accuracy score. In this case, the readability and acceptability was still high but it did affect the accuracy because the foothill slopes was translated into sebuah anak bukit which was different in meaning and the reader received the different description.

\subsection{Simile}

ST087/C3/P67 : The next minute Curley was flopping like a fish

on a line, and his closed fist was lost in Lennie's big hand. 
TT087/C3/P87 : Menit selanjutnya Curley berkelojotan seperti

ikan di tali pancing, dan tinjunya terbenam di dalam tangan Lennie yang besar. (Ariyantri)

TT087/C3/P69

: Semenit kemudian Curley meliuk-liukkan seperti

ikan kena panas dan tinjunya tenggelam dalam genggaman besar

Lennie.(Pramoedya)

The data above was the example of simile. Simile in source text was the next minute Curley was flopping like a fish on a line The data was categorized as simile because it was comparison of two things and the conjunction used is "like". It was translated into menit selanjutnya berkelojotan seperti ikan di tali by Ariyantri meanwhile Pramoedya translated into semenit kemudian Curley meliuk-liukkan seperti ikan kena panas. Ariyantri deployed established equivalent and closely come to the source text meanwhile Pramoedya deployed modulation techniques that convey with the figurative meaning with different comparison from the source text even though the meaning is still same which was expressed the way Curley behaved in his horrible situation while fighting with Lennie.

\subsection{Satire}

ST113/C6/P104 : The poor bastard's nuts. Don't shoot him. He didn't know what he was doing TT113/C6/P130: Bajingan malang itu sinting. Jangan tembak dia. Dia tidak paham apa yang dia lakukan. (Ariyantri) Established Equivalent TT113/C6/P94: Si anak sundal itu tak betul otaknya. Jangan tembak dia. Dia tak tahu apa yang diperbuatnya sendiri. (Pramoedya) Modulation

The data was the example of satire. The sentence the poor bastard's nuts was translated into bajingan malang itu sinting by Ariyantri meanwhile Pramoedya was translated into si anak sundal itu tak betul otaknya. Ariyantri was translated using established equivalent and the quality was high in accuracy, acceptability, and readability. Further Pramoedya was translated with different form but the meaning was still same. The meaning still deployed satire.

\subsection{Personification}

ST017/C1/P8 : : The sycamore limbs rustled under a little wind that

died immediately.

TT017/C1/P15 : Batang-batang pohon ara menggerisik dalam embusan angin sepoi yang hilang dengan cepat. (Ariyantri)

TT017/C1/P13 : Batang-batang sycamore melambai-lambai dibuai angin yang berhenti lagi sebentar kemudian (Pramoedya)

The above shown data was personification. The sentence the sycamore limbs rustled under a little wind that died immediately was translated into batangbatang pohon ara menggerisik dalam embusan angin sepoi yang hilang dengan cepat. It was translated using established equivalent and reduction. The reduction 
was in that died immediately which was translated into yang hilang dengan cepat meanwhile the sycamore limbs belongs to established equivalent in which it was translated into batang-batang pohon ara. The translation version had middle score in accuracy but still high in terms of acceptability and readability. Further, Pramoedya also used established equivalent in translated the sycamore limbs which was translated into batang-batang sycamore. Then, Pramoedya used discursive creation in the following words rustled under a little wind that died immediately was translated into melambai-lambai dibuai angin yang berhenti lagi sebentar kemudian. The target text was good in terms of acceptability and readability for the readers but the accuracy was also in middle score. It did not remain high because the translation version was far translated from the source text.

\subsection{Sarcasme}

ST047/C2/P25 : "Be a damn good thing if you was," George said viciously. "Save ever'body a hell of a lot of trouble."

TT047/C2/P36 : "Bagus kalau itu terjadi,"kata George pedas."Jadi

berkurang masalah buat semua orang." (Ariyantri) Modulation

TT047/C2/P28 : "Jahanam, baiknya kalau memang begitu,"bentak

George marah. "Kalau tidak, aduhai, orang akan lepas dari kesialanmu." (Pramoedya) Discursive Creation

The above data was categorized into sarcasm. Sarcasm is the most savage sarcastic language. This figure of speech was always hurtful. "Save ever'body a hell of a lot of trouble." was translated into jadi berkurang masalah buat semua orang. Besides, Pramoedya was translated into Kalau tidak, aduhai orang akan lepas dari kesialanmu. Ariyantri used modulation and the translation quality was high. Modulation is a technique that changes the point of view in translating. Meanwhile, Pramoedya used discursive creation and it influenced the translation quality which made the accuracy was low.

\subsection{Irony}

ST048/C2/P25 : : “Well, that was a lie. An' I'm damn glad it was. If I was a relative of yours I'd shoot myself."

TT048/C2/P36 : "Yah, itu bohong, aku pasti sudah menembak diriku sendiri." (Ariyantri) Modulation

TT048/C2/P28 : "Ya, itu memang bohong. Dan alangkah jahanam kenangku karena bukan. Kalau engkau familiku, kutembak kepalaku ini." (Pramoedya) Discursive Creation

The example data was an example of irony, the sentence if I was a relative of yours, I'd shoot myself was translated into aku pasti sudah menembak diriku sendiri by Ariyantri using modulation. In addition, Pramoedya used discursive creation and translated into kalau engkau familiku, kutembak kepalaku ini.Again, the creative discursion was applied by Pramoedya. 


\subsection{Hyperbole}

ST061/C2/P35: There was a gravity in his manner and a quiet so profound that all talk stopped when he spoke. TT061/C2/P49: Ada daya tarik dalam gerak geriknya dan sikap tenang yang begitu dalam, sehingga semua pembicaraan terhenti ketika ia bicara. (Ariyantri) TT061/C2/P38 : adalah suatu gaya dalam langkah lakunya dan dalam kelembutan suaranya hingga semua percakapan terhenti bila ia membuka mulut. (Pramoedya)

Data above was categorized as hyperbole. Hyperbole is kind of figure of speech that exaggerating something. It was a description of Slim. The firm character on the ranch that has his own charisma and were loved by all workers even the owner's sons felt discourage towards him. Pramoedya used discursive creation in translating this figure of speech and gave the meaning far from the context.

\subsection{Repetition}

ST099/C4/P84: Candy's face had grown redder and redder, but before she was done speaking, he had control of himself.

TT099/C4/P10: Wajah Candy semakin memerah, tapi sebelum perempuan itu selesai bicara, lelaki tua itu berhasil mengendalikan diri. (Ariyantri)

TT099/C4/P79: Muka Candy kian lama kian merah, tapi sebelum perempuan itu habis berbicara ia telah dapat membesarkan perasaanya. (Pramoedya)

The last figure of speech found in novel Of Mice and Men is repetition; the data was candy's face had grown redder and redder. The context was because he felt angry towards Curley's wife and he felt very annoyed. The repetition was translated into wajah Candy semakin memerah by Ariyantri. Besides, Pramoedya was translated into muka Candy kian lama kian merah. The figure of speech found in this novel was in line with theory proposed by Keraff (2010) and the translation techniques chosen was well deployed techniques proposed by Molina \& Hurtado Albir (2002).

From deploying the translation techniques, it drove us to realize that Pramoedya never fail to translate figure of speech beautifully, his translation was good but it did felt like he had his style in transferring the language and it was not because his ideology as male translator. If it was because his gender, the case was about translated figurative language into non figurative language while this case shown the vice versa.

Regard to this matter, the researcher found previous researches that Pramoedya as the novelist was famous because of his fabulous figure of speech. Schrer (2012) explained the perseverance of Pram in defending his ideology towards literary groups in those days. Scherer used all Pram writings for her research. Meanwhile, Teuw (1997) examines Pram as a writer who has different characters and language styles. It can be seen from his writings like his tetralogy Buru (Bumi 
Manusia, Anak Semua Bangsa,Jejak Langkah and Rumah Kaca), entitled Bumi Manusia, Pram rejected the social hierarchy that the ordinary people must respect more to respectable people.

To support this case, the theory proposed by Venuti (2008)should be firmed hold by the translator is the more fluent the translation, the more invisible the translator. In other words, to come closely to the source text, the translator should faith to the source text and being invisible in target text. Translator must be loyal to the source text and must be careful in replacing meaning from source to target language (Sutopo, 2015). The translator cannot gain exsesssively or loss to much information from the source text that will affect the readers understanding toward the translation text. Both the reader and translator is actually the consumer of the source text. Since the translators is the first consumer to be a bridge for the target readers that is why the translation activity cannot be meaningless.

\section{CONCLUSION}

There were 8 kinds figure of speech found in this novel. There were metaphor, simile, satire, personification, sarcasm, irony, hyperbole, and repetition. In total, there were 121 data. Metaphor $39.7 \%$, Simile $14.9 \%$, Satire $10.8 \%$, Personification $10.8 \%$, Sarcasm $9.09 \%$, Irony $8.3 \%$, Hyperbole $5 \%$, and repetition $1.7 \%$. Meanwhile, the translation technique were applied by both translator were varied and it found that the translation quality of Ariyantri's translation was 2.92 which means high due to the most applied techniques was established equivalent and Pramoedya was 2.52 in average which means that the quality is medium. In Pramoedya's translation version was medium in quality due to the most applied factors was established equivalent but the number was not significant in total of all data and followed by discursive creation and other combination techniques that lower the accuracy. The result showed that the background translator which play important role was not their gender but their background as the experienced author compare to experienced translator. This research found that the famous name as the writer cannot always work well as the translator also because he could not be an invisible translator.

For further research, the analysis of other work of authors who become translator is still obviously needed. The following research also can chose author who work as translator in modern generation and compare it to author who work as translator from old generation.

\section{REFERENCES}

Ekawati, Sumarwati, A. (2012). GAYA BAHASA DALAM NOVEL TERJEMAHAN SANG PENGEJAR LAYANG-LAYANG ( THE KITE RUNNER ) KARYA KHALED HOSSEINI. BASASTRA Jurnal Penelitian Bahasa Dan Sastra Indonesia Dan Pengajarannya., 1 Nomor 2(ISSN 123026405), 153-169.

Fernández Guerra, A. (2012). Translating culture: problems, strategies and practical realities. [Sic] - a Journal of Literature, Culture and Literary Translation, 
(1.3), 1-27. https://doi.org/10.15291/sic/1.3.1t.1

Hendrastuti, R., Nababan, M. R., \& Wiratno, T. (2013). Kajian Terjemahan Metafora yang Menunjukkan Sikap dalam Buku Motivasi The Secret. TransLing Journal: Translation and Linguistics, 1(1), 21-35.

Hurtado Albir, A., \& Taylor, P. (2015). The Acquisition of Translation Competence. Competences, Tasks, and Assessment in Translator Training. Meta: Journal Des Traducteurs, 60(2), 256. https://doi.org/10.7202/1032857ar

Keraf, Gorys. 2010. Diksi Dan Gaya Bahasa. Jakarta: PT Gramedia Pustaka Utama. Lilasari, L. N. T. (2012). The Translation of Live Metaphor in Harry Potter and The Deathly Hallows into "Harry Potter dan relikui Kematian."(Master's Thesis).Available from Theses Database.

Moloeng, Lexy J.2004. Metode Penilaian Kualitatif. Bandung:Remaja Rosdakarya

Molina, L., \& Hurtado Albir, A. (2002). Translation Techniques Revisited: A Dynamic and Functionalist Approach. Meta: Journal Des Traducteurs, 47(4), 498. https://doi.org/10.7202/008033ar

Murtafi, A., Nababan, M. R., \& Djatmika. (2017). The translation analysis of repetition language style in novel a thousand splendid suns, the technique and quality (translation study using stylistics approach). Prasasti, 2(1), 1-20.

Nababan, M. (2012). Pengembangan model penilaian kualitas terjemahan. Kajian Linguistik Dan Sastra, 24(1), 39-57. Retrieved from https://publikasiilmiah.ums.ac.id/bitstream/handle/11617/2220/4. Mangatur Nababan.pdf;sequence $=1$

Newmark, P. (1988). Textbook of Translation. Prentice-Hall International: The University of Michigan

Nida, E., \& Taber, C. (1982). The Theory and Practice of Translation. Leiden:J.Brill

Nila, S. (2013). Teknik Penerjemahan Metafora, Simile, Dan Personifikasi Dalam Novel The Kite Runner Dan Dampaknya Terhadap Kualitas Terjemahan. (Master's Thesis).Available from Theses Database.

Rahayu, P. (2008). Analisis ragam bahasa pria dan ragam bahasa wanita dalam novel das Superweb karya Hera Lind ditinjau dari implikatur percakapan.

Santosa,R.2014.Metode Penelitian Kualitatif. Surakarta: FSSR UNS

Scherer, Savitri. 2012. Pramoedya Ananta Toer Luruh dalam Ideologi. Terjemahan Dalih Sembiring, Astrid Reza, Abmi Handayani. Cetakan ke-2 Jakarta:Komunitas Bambu.

Steinbeck, J. (1965). 937 of Mice and Men. United States of America:Penguin Books.

Steinbeck, John. 2017. Tikus Dan Manusia. Jakarta: PT.Gramedia Pustaka Utama

Steinbeck, John: 2013.Tikus Dan Manusia. Jakarta: Lentera Dipantara

Suprajaheni, O. (2011).The Translation of Metaphors in the Novel the Stars Shine Down into Kemilau Bintang Menerangi Bumi. (Thesis). Yogyakarta: Gadjah Mada University

Suryasa, I. W. (2016). Figurative Language Found in Printed Advertisement, 2(1), 42-60. https://doi.org/10.6084/m9.figshare.3407089.v1

Sutopo, Anam. 2015. Penerjemahan Naskah Resmi:Telaah Holistik Pidato Kenengaraan. Solo:MUP Press UMS 
Suyawinata, Z. (2003). Translation: bahasan teori \& penuntun praktis menerjemahkan. Yogyakarta: Kanisius

Taylor, C. (2017). The relationship between irony and sarcasm: Insights from a firstorder metalanguage investigation. Journal of Politeness Research, 13(2), 209241. https://doi.org/10.1515/pr-2015-0037

Teuw, A. 1997. Citra Manusia Indonesia dalam Karya Sastra Pramoedya Ananta Toer. Jakarta:Pustaka Jaya.

Venuti, L. (2008). The Tr an s l a to $r$ 's I $n v$ is ib ility: a history of translation. Routledge, 270 Madison Ave, New York.

Wahyuni, D. (2015). Speech Features Used By Margaret Thatcher in TV Interviews.(Master's Thesis).Yogyakarta:Gadjah Mada University

Widiyantari, Y. (2012). The Strategy To Translate Metaphor. REGISTER. https://doi.org/http://dx.doi.org/10.18326/rgt.v5i1.49-72 